\title{
Disruption of GpI mGluR-Dependent Cav2.3 Translation in a Mouse Model of Fragile X Syndrome
}

\author{
Erin E. Gray, ${ }^{1}$ Jonathan G. Murphy, ${ }^{1,2}$ Ying Liu, ${ }^{1}$ Ivan Trang, ${ }^{1}$ @G. Travis Tabor, ${ }^{1}$ Lin Lin, ${ }^{1}$ and $\odot$ Dax A. Hoffman ${ }^{1}$ \\ ${ }^{1}$ Molecular Neurophysiology and Biophysics Section, Program in Development Neuroscience, National Institute of Child Health and Human Development, \\ National Institutes of Health, Bethesda, Maryland 20892, and ²National Institute of General Medical Sciences, National Institutes of Health, Bethesda, \\ Maryland 20892
}

Fragile X syndrome (FXS) is an inherited intellectual impairment that results from the loss of fragile X mental retardation protein (FMRP), an mRNA binding protein that regulates mRNA translation at synapses. The absence of FMRP leads to neuronal and circuit-level hyperexcitability that is thought to arise from the aberrant expression and activity of voltage-gated ion channels, although the identification and characterization of these ion channels have been limited. Here, we show that FMRP binds the mRNA of the R-type voltagegated calcium channel Cav2.3 in mouse brain synaptoneurosomes and represses Cav2.3 translation under basal conditions. Consequently, in hippocampal neurons from male and female FMRP KO mice, we find enhanced Cav2.3 protein expression by western blotting and abnormally large R currents in whole-cell voltage-clamp recordings. In agreement with previous studies showing that FMRP couples Group I metabotropic glutamate receptor (GpI mGluR) signaling to protein translation, we find that GpI mGluR stimulation results in increased Cav2.3 translation and R current in hippocampal neurons which is disrupted in FMRP KO mice. Thus, FMRP serves as a key translational regulator of Cav2.3 expression under basal conditions and in response to GpI mGluR stimulation. Loss of regulated Cav2.3 expression could underlie the neuronal hyperactivity and aberrant calcium spiking in FMRP KO mice and contribute to FXS, potentially serving as a novel target for future therapeutic strategies.

Key words: Fragile X; FMRP; R-type Calcium Channel; Cav2.3; mRNA

Significance Statement

Patients with fragile X syndrome (FXS) exhibit signs of neuronal and circuit hyperexcitability, including anxiety and hyperactive behavior, attention deficit disorder, and seizures. FXS is caused by the loss of fragile X mental retardation protein (FMRP), an mRNA binding protein, and the neuronal hyperexcitability observed in the absence of FMRP likely results from its ability to regulate the expression and activity of voltage-gated ion channels. Here we find that FMRP serves as a key translational regulator of the voltage-gated calcium channel Cav2.3 under basal conditions and following activity. Cav2.3 impacts cellular excitability and calcium signaling, and the alterations in channel translation and expression observed in the absence of FMRP could contribute to the neuronal hyperactivity that underlies FXS.

\section{Introduction}

Fragile X syndrome (FXS) is the most common form of inherited intellectual disability in humans, and is further characterized by autistic behavior, childhood seizures, and abnormal dendritic

Received May 25, 2017; revised June 13, 2019; accepted June 19, 2019.

Author contributions: E.E.G., J.G.M., Y.L., and D.A.H. designed research; E.E.G., J.G.M., Y.L., I.T., G.T.T., and L.L. performed research; E.E.G., J.G.M.,Y.L., I.T., G.T.T., and L.L. analyzed data; E.E.G., J.G.M., and D.A.H. wrote the paper.

This work was supported by the Intramural Research Program of the Eunice Kennedy Shriver National Institute of Child Health and Human Development and National Institute of General Medical Sciences Postdoctoral Research Associate Training Grant FI2 GM12004 to J.G.M. We thank Drs. Jiahua Hu, Jakob Gutzmann, Eunyoung Kim, and Emilie Campanac for valuable discussions, protocols, and experimental assistance; and James Demacek and Vincent Schram (National Institute of Child Health and Human Development Microscopy \& Imaging Core) for technical assistance.

The authors declare no competing financial interests.

Correspondence should be addressed to Dax A. Hoffman at hoffmand@mail.nih.gov. spine formation. FXS arises from the transcriptional silencing of the fragile X mental retardation protein (FMRP), an RNA binding protein that regulates the localization and translation of a specific subset of mRNAs in neurons, particularly within dendrites (Richter et al., 2015). FMRP typically acts to repress translation of its mRNA targets under basal conditions, whereas stimulation of Group I (GpI) mGluRs triggers the release of FMRP from its associated transcripts to allow their translation, resulting in LTD of synaptic transmission (mGluR-LTD) (Hou et al., 2006; Gross et al., 2010; Nalavadi et al., 2012; Niere et al.,

G.T. Tabor's present address: Medical Scientist Training Program, Washington University School of Medicine, St. Louis, M0 63110.

https://doi.org/10.1523/JNEUROSCI.1443-17.2019

Copyright $\odot 2019$ the authors 
2012). In FMRP KO mice, mGluR-LTD is enhanced and no longer requires new protein synthesis (Huber et al., 2002; Hou et al., 2006; Nosyreva and Huber, 2006). It is thought that target mRNAs are no longer translated in response to mGluR-dependent signaling in the FMRP KO and instead exhibit unregulated, exaggerated basal dendritic protein expression (Waung and Huber, 2009).

Due to the loss of FMRP-dependent regulation, FMRP KO mice and FXS patients exhibit hyperactivity, seizures, and sensory hypersensitivity (Contractor et al., 2015). This neuronal and circuit-level hyperexcitability likely results from the ability of FMRP to regulate the abundance or activity of voltage-gated ion channels. For instance, FMRP binds the mRNA of the axosomatic delayed rectifier potassium channel $\mathrm{Kv} 3.1 \mathrm{~b}$ to regulate its expression, ultimately altering the firing properties of neurons in the medial nucleus of the trapezoid body (Strumbos et al., 2010; Darnell et al., 2011; El-Hassar et al., 2019). While the mechanism varies by channel and brain region, the dendritic voltage-gated potassium channel Kv4.2 (Gross et al., 2011; Lee et al., 2011), large conductance calcium- and voltage-activated potassium (BK) channel (Zhang et al., 2014), and hyperpolarizationactivated cyclic nucleotide-gated potassium (HCN1) channel (Brager et al., 2012; Zhang et al., 2014) undergo regulation by FMRP, leading to enhanced dendritic excitability and plasticity (Brager et al., 2012; Routh et al., 2013; Zhang et al., 2014).

The increase in cellular excitability in neurons lacking FMRP is accompanied by enhanced dendritic calcium spiking (Routh et al., 2013; Zhang et al., 2014). This is despite reduced functional availability of L-type voltage-gated calcium channels (VGCCs) (Meredith et al., 2007). Regulation of other dendritic VGCCs by FMRP has not been investigated, although recent data have shown that FMRP can bind Cav2.3 mRNA (Darnell et al., 2011). Cav2.3 is highly expressed in the dendrites of CA1 hippocampal neurons (Magee and Johnston, 1995; Parajuli et al., 2012), where it generates large calcium spikes in response to both backpropagating action potentials and synaptic activity (Bloodgood and Sabatini, 2007). Cav2.3 channels enhance neuronal excitability by contributing to action potential burst firing, postburst afterdepolarizations, and plateau potentials in neuronal dendrites (Magee and Carruth, 1999; Metz et al., 2005; Takahashi and Magee, 2009). Moreover, Cav2.3-mediated R current is enhanced following GpI mGluR stimulation and underlies aspects of mGluR-dependent increases in excitability (Park et al., 2010). In addition, mGluR-LTD can be blocked in the presence of a Cav2.3 antagonist (Oliet et al., 1997), suggesting that Cav2.3 might be important for this type of plasticity.

Given the importance of Cav2.3 in cellular excitability, calcium signaling, and GpI mGluR modulation, we investigated the possibility that Cav2.3 mRNA can be regulated by FMRP and the potential consequences of this interaction. We show here that FMRP binds Cav2.3 mRNA and represses Cav2.3 translation under basal conditions. Following GpI mGluR stimulation, FMRP releases this translational repression to increase Cav2.3 protein expression in neurons and isolated synaptoneurosomes. Furthermore, GpI mGluR-mediated increases in total protein levels led to increased R-current density in whole-cell recordings of hippocampal neurons. Thus, FMRP serves as a key translational regulator of both basal Cav2.3 expression and following mGluR agonist stimulation that is known to induce mGluR-dependent forms of plasticity. Considering the impacts of Cav2.3 on cellular excitability and calcium signaling, alterations in channel mRNA translation and expression could underlie the neuronal hyperactivity and aberrant calcium spiking in FMRP KO mice that contributes to FXS.

\section{Materials and Methods}

All animal procedures were performed in accordance with guidelines approved by the National Institute of Child Health and Human Development Animal Care and Use Committee.

Rodent genetics and breeding. WT C57BL/6J (The Jackson Laboratory) and FMRP KO $\left(F m r r^{t m 1 C g r} / \mathrm{J}\right.$, stock \#003025) were obtained from the Jackson Laboratory. The mGluR5 KO strain $\left(G r m 5^{t m 1 R o d} / \mathrm{J}\right.$, fully backcrossed into the C57BL/6J background) was a generous gift from Dr. Paul Worley (Johns Hopkins University). For all experiments using WT and FMRP KO hippocampal tissue, experiments were performed using littermates generated from FMRP heterozygote breeding. For all other experiments, lines were maintained independently on a C57BL/6J background. Cultured rat hippocampal neurons were isolated from E18-E19 timed pregnant Sprague Dawley rats obtained from Taconic Biosciences at E14.

DNA constructs. Human Cav2.3-GFP was kindly provided by Dr. Ehud Isacoff (Ulbrich and Isacoff, 2007) and was subcloned into a CMVdriven EGFP vector (Invitrogen). This construct contains the human Cav2.3 (accession number NM_000721) coding region and the first 122 nucleotides of the 3' UTR. The Kv4.2-3'UTR-Venus construct was commercially generated by Bionnovatise and contains: 212 bp of the Kv4.2$5^{\prime}$ UTR with a myristoylation sequence (generated by gene synthesis), the Venus fluorescent protein ORF, and the 2479 bp Kv4.2 3'UTR (PCR cloned from brain tissue cDNA) in AgeI and NotI sites of the vector pCAG. The FLAG-FMRP-mCherry plasmid was generously provided by Dr. Gary Bassel (Gross et al., 2010).

Hippocampal and cortical tissue preparation. Three-week-old male mice were deeply anesthetized with isoflurane, killed by decapitation, and brains rapidly removed into an ice-cold solution containing HBSS and $15 \mathrm{~mm}$ HEPES for dissection. Once isolated, the cortex and hippocampus were immediately homogenized on ice in lysis buffer or further processed for synaptoneurosome isolation.

Synaptoneurosome isolation. Synaptoneurosomes were prepared using a standard approach (Muddashetty et al., 2007) by gently homogenizing hippocampal tissue freshly isolated from 2 mice with a Dounce homogenizer in $1.0 \mathrm{ml}$ synaptoneurosome buffer containing $20 \mathrm{~mm}$ HEPES, $\mathrm{pH}$ 7.4, $124 \mathrm{~mm} \mathrm{NaCl}, 3 \mathrm{~mm} \mathrm{KCl}, 1.0 \mathrm{~mm} \mathrm{KH}_{2} \mathrm{PO}_{4}, 26 \mathrm{~mm} \mathrm{NaHCO}_{3}, 1.0 \mathrm{~mm}$ $\mathrm{MgCl}_{2}, 2.0 \mathrm{~mm} \mathrm{CaCl}_{2}, 10 \mathrm{~mm}$ glucose, Halt protease inhibitor mixture (Thermo Fisher Scientific), and complete mini protease inhibitor (Roche Diagnostics). The homogenate was then loaded into a syringe and passed through a prewetted $100 \mu \mathrm{m}$ nylon net filter in a Swinnex holder (Millipore) two times before passing once through a $5 \mu \mathrm{m}$ nylon net filter. The filtrate was centrifuged at $1000 \times \mathrm{g}$ for $20 \mathrm{~min}$ at $4^{\circ} \mathrm{C}$, and the resulting pellet was carefully resuspended in $800 \mu \mathrm{l}$ of synaptoneurosome buffer and kept on ice before the start of the experiment.

Cultured hippocampal neurons. Primary cultures were prepared by papain digestion of hippocampal tissue dissected from embryonic day 18-19 rat or mouse pups using standard protocols. In experiments comparing WT and FMRP KO cultures, the neuronal preparations for both genotypes were performed in parallel to ensure consistency. For western blotting and mRNA stability assays, neurons were plated at $8.5 \times 10^{5}$ cells per well of a 6 -well plate precoated with poly-D-lysine. At 4 DIV, neurons were fed $2.5 \mu \mathrm{M}$ cytosine $\beta$-D-arabinofuranoside to inhibit glial growth, and thereafter fed twice per week with glial-conditioned medium. For electrophysiology, mouse neurons were seeded at $1.0 \times 10^{5}$ cells/well in a 24-well cell culture plate. Rat neurons were seeded at $1.0 \times$ $10^{5}$ cells/well in a 12-well plate. Rat and mouse neurons were grown on precoated $12 \mathrm{~mm}$ glass coverslips (BD Biosciences) and fed twice per week with Neurobasal A supplemented with 2\% B27 and 1\% Glutamax.

RNA immunoprecipitation (RIP). Human embryonic kidney (HEK293) cells were maintained in DMEM supplemented with $10 \% \mathrm{FBS}$ at $37^{\circ} \mathrm{C}$ in $5 \% \mathrm{CO}_{2}$. Cells were transiently transfected with 500 ng DNA at $\sim 50 \%$ confluence using X-tremeGENE 9 (Roche Diagnostics) transfection reagent. Transfected HEK293T cells ( $40 \mathrm{~h}$ after transfection) were washed with PBS, lysed and collected in RIP lysis buffer (PBS, $200 \mathrm{~mm} \mathrm{NaCl}, 1 \%$ NP-40) supplemented with protease inhibitor mixture (Thermo Fisher Scientific) and RNase inhibitor (Invitrogen). After $10 \mathrm{~min}$ of incubation on ice, followed by centrifugation at $16,000 \times g$ for $10 \mathrm{~min}$ at $4^{\circ} \mathrm{C}$, the 
lysates were incubated with $10 \mu \mathrm{g}$ anti-Flag antibody (Sigma-Aldrich) bound protein $\mathrm{G}$ magnetic beads (Bio-Rad) at $4^{\circ} \mathrm{C}$ overnight; $10 \%$ of the total lysate was saved as input sample for RNA extraction. For experiments from mouse brain tissue, the cortex and hippocampus from 3 -week-old WT and FMRP KO mice were lysed by homogenization in lysis buffer (PBS, 1\% NP-40, $200 \mathrm{~mm} \mathrm{NaCl}$, protease inhibitor mixture, RNase inhibitor) and spun down briefly to exclude nuclei. For RNA IP from synaptoneurosomes, supernatants were brought to $400 \mathrm{~mm} \mathrm{NaCl}$ and centrifuged for $40 \mathrm{~min}$ at $4^{\circ} \mathrm{C}$ and $20,000 \times \mathrm{g}$. The synaptoneurosomes were precleared with $60 \mu \mathrm{l}$ of protein $\mathrm{G}$ magnetic beads for $2 \mathrm{~h}$ at $4^{\circ} \mathrm{C}$, and an aliquot (10\%) of precleared supernatant ("input") was saved for RNA extraction. Precipitation was performed overnight at $4^{\circ} \mathrm{C}$ with 5 $\mu \mathrm{g}$ of antibody-bound protein $\mathrm{G}$ magnetic beads, blocked beforehand with either anti-FMRP antibody (Developmental Studies Hybridoma Bank, 7G1-1) or normal mouse IgGs. RNA was extracted immediately from the immunoprecipitates and $10 \%$ of input lysates for further analysis.

$R N A$ isolation and $q R T-P C R$. Total RNA was extracted from RIP samples or directly from primary cultures of mouse hippocampal neurons and hippocampal tissue using Trizol Reagent, followed by purification using RNeasy Mini Kit reagents and column DNase digestion (QIAGEN) to remove genomic DNA contamination. cDNA was reverse-transcribed using SuperScript III Reverse Transcriptase (Invitrogen) and random hexamer primers. Real-time PCR was performed using Power SYBR Green PCR Master Mix (Applied Biosystems) in 384-well plate in ABI ViiA 7 Sequence Detection PCR System. The PCR was performed in a 15 $\mu \mathrm{l}$ reaction mixture containing $0.2 \mu \mathrm{l} \mathrm{cDNA}$ as a template and $350 \mathrm{~nm}$ specific oligonucleotide primer pairs using program: denaturation at $95^{\circ} \mathrm{C}$ for $15 \mathrm{~s}$; annealing and extension at $60^{\circ} \mathrm{C}$ for $1 \mathrm{~min}$ for $40 \mathrm{cycles}$. The melting curve of each sample was measured to ensure the specificity of the products. The primers used were the following: EGFP vector: forward 5'-GAGCAAAGACCCCAACGAGA-3', reverse 5'-TTGTACAGCTC GTCCATGCC-3'; Cav2.3-GFP: forward $5^{\prime}$-GTCCCGAAGACTGGA GAAGAC-3', reverse 5'-AGCCATTGCGGAGGTAAGAG-3'; Kv4.23'UTR-Venus: forward 5'-TAGGACAGTGCTAGGCACAC-3', reverse 5'-GTAAAGCCAGGTCTTCCCGA-3'; mouse Cav2.3: forward 5'CATGTGGCCGCATCCATTAC-3', reverse 5'-GACCAGCCTCTTA TAGGCCAC-3'; and mouse Kv4.2: forward 5'-GCGCCACCTTGGA ATAATCG-3', reverse 5'-TCTGGAAGTGGAGGTCACGA-3'. The immunoprecipitated signals with Flag (transfected 293T cells) or FMRP antibody (mouse brain tissues) were normalized to the input of each sample. Levels of mRNA from primary cultures of mouse hippocampus neurons and hippocampus tissue were normalized to $18 \mathrm{~S}$ ribosomal RNA (Applied Biosystems).

FISH. Whole mouse brains were isolated from 3- to 4-week-old WT or FMRP KO male littermates immediately following isoflurane anesthesia and decapitation. Brains were flash frozen on dry ice and stored at $-80^{\circ} \mathrm{C} ; 10-\mu \mathrm{m}$-thick coronal sections were collected onto room temperature glass slides (Superfrost Plus, Thermo Fisher Scientific). The cryostat (Leica Biosystems) chamber and holder were set at $-19^{\circ} \mathrm{C}$ and $-16^{\circ} \mathrm{C}$, respectively. Once mounted, sections were immediately frozen in the cryostat chamber before transfer to a slide box on dry ice. Sections were fixed on ice with $4 \%$ PFA in PBS, pH 7.4, and dehydrated by serial immersion in $50 \%, 70 \%$, and $2 \times 100 \%$ ethanol for 5 min each. After dehydration, a hydrophobic barrier was drawn around the sections using a PAP pen (Vector Laboratories). Fluorescence detection of CaMKII $\alpha$ and Cav2.3 mRNA was performed according to the RNAScope manufacturer's protocol (Advanced Cell Diagnostics). Briefly, sections were permeabilized with Protease IV at room temperature for $30 \mathrm{~min}$ and washed with PBS. All of the following hybridization steps were performed at $40^{\circ} \mathrm{C}$ in the HybEZ hybridization oven (Advanced Cell Diagnostics). All wash steps were $2 \times 2$ min immersions in RNAScope Wash Buffer (Advanced Cell Diagnostics). The targeted mRNAs were hybridized with RNAScope $\mathrm{Z}$ probes for $2 \mathrm{~h}$, washed, and hybridized with RNAscope preamplifier probes for $30 \mathrm{~min}$. After washes, amplifier probes were hybridized for $15 \mathrm{~min}$, washed, and detection reagents were hybridized for $30 \mathrm{~min}$. A final $15 \mathrm{~min}$ fluorescent labeling step preceded addition of a coverslip $(24 \times 40 \mathrm{~mm}$, Corning \#1) using DAPI containing antifade mounting medium (Thermo Fisher Scientific). All fluorescence images were captured on an inverted Carl Zeiss 710 confocal microscope using a $40 \times 1.4 \mathrm{NA}$ oil objective. For each animal, the hippocampus was imaged from coronal slices by capturing full-field tiles, 6 in the ventraldorsal and 5 in the medial-lateral planes using 10\% overlap within the Carl Zeiss Zen Software suite. Tiled images were exported as stitched TIFFs, and staining was analyzed in ImageJ software; $600 \mu \mathrm{m} \times 250 \mu \mathrm{m}$ rectangular regions containing the ventral-dorsal extent of the stratum oriens, stratum pyramidale, and stratum radiatum adjacent to the dorsal arm of the granule cell layer were cropped from the stitched hippocampal images to normalize variances in the anatomy of the hippocampus from animal to animal. Using the Threshold and Analyze Particles function in ImageJ, puncta were identified and particle density and size were exported for comparisons between WT and FMRP KO mouse brain. All particles $\leq 2$ pixels were rejected from the analysis. Data visualization and statistical comparisons were done using Prism 6 (GraphPad).

Western immunoblotting. Hippocampal tissue from WT and FMRP KO male littermates and 20-22 DIV neuronal cultures were homogenized in lysis buffer containing 1\% CHAPS, $50 \mathrm{~mm}$ Tris, pH 7.4, $100 \mathrm{~mm}$ $\mathrm{NaCl}, 10$ mm EDTA, 10 mm EGTA, 1 mm PMSF, Halt protease inhibitor mixture (Thermo Fisher Scientific), and cOmplete mini protease inhibitor (Roche Diagnostics). The lysates were sonicated briefly before determining the protein concentration using the BCA assay, and then denatured in loading buffer supplemented with reducing agent (Invitrogen); $10 \mu \mathrm{g}$ of total protein was loaded per lane on precast $3 \%-8 \%$ gradient NuPAGE acrylamide gels (Invitrogen). Western blots were probed with primary antibodies against Cav2.3 [1:200 rabbit antibody from Alomone Labs or 1:2000 guinea pig antibody generously provided by Dr. Yugo Fukazawa (Parajuli et al., 2012)], $\beta$-actin (1:40,000, SigmaAldrich), GFP (1:20,000, Abcam), and mGluR5 (1:2500, Abcam).

Electrophysiology. To isolate Cav2.3-mediated R current in mouse neurons, whole-cell voltage-clamp experiments from cultured hippocampal neurons were performed at $14-21$ DIV in room temperature $\left(22^{\circ} \mathrm{C}\right.$ $24^{\circ} \mathrm{C}$ ) extracellular solution containing the following (in mM): $125 \mathrm{NaCl}$, 20 TEA-Cl, $3 \mathrm{KCl}, 1 \mathrm{MgCl}_{2}, 10 \mathrm{HEPES}, 15$ glucose, and $2 \mathrm{CaCl}_{2}$, pH 7.4. Before the start of an experiment, coverslips were preincubated for $>30$ min in extracellular solution containing $200 \mathrm{~nm}$ agatoxin IVA, $2 \mu \mathrm{M}$ $\omega$-conotoxin GVIA, $2 \mu \mathrm{M} \omega$-conotoxin MVIIC, and $0.1 \mathrm{mg} / \mathrm{ml}$ cytochrome-c. After preincubation, neurons were transferred to extracellular solution, and recordings were made no longer than $1 \mathrm{~h}$ to ensure maintenance of P/Q and N VGCC block. Extracellular solution contained the blockers $1.0 \mu \mathrm{M}$ TTX, $1 \mathrm{~mm} 4$-AP, $10 \mu \mathrm{M}$ CNQX, $2 \mathrm{~mm} \mathrm{CsCl}$, and $20 \mu \mathrm{M}$ nifedipine (Tocris Bioscience). Recording pipettes $(4-6 \mathrm{M} \Omega$ ) were filled with intracellular solution composed of the following (in $\mathrm{mM}$ ): 110 Cs Gluconate, 25 TEA-Cl, 10 HEPES, 1 EGTA, 4 Mg-ATP, 0.5 NaGTP, and $10 \mathrm{Na}$-phosphocreatine, $\mathrm{pH}$ 7.3. Whole-cell voltage-clamp recordings of isolated $\mathrm{R}$ current in cultured rat hippocampal neurons were performed as above with the following modifications: extracellular solution contained the following (in $\mathrm{mm}$ ): $110 \mathrm{NaCl}, 20$ TEA-Cl, $3 \mathrm{KCl}$, 1.2 $\mathrm{MgCl}_{2}, 10 \mathrm{HEPES}, 10$ glucose, and $10 \mathrm{BaCl}_{2}, \mathrm{pH}$ 7.4. Before the start of an experiment, coverslips were preincubated for $>30 \mathrm{~min}$ in extracellular solution containing $1.0 \mu \mathrm{M} \omega$-conotoxin GVIA and $3.0 \mu \mathrm{M}$ $\omega$-conotoxin MVIIC. During recordings, the blockers $2.0 \mathrm{~mm} \mathrm{CsCl}, 10.0$ $\mu \mathrm{M}$ CNQX, $0.5 \mu \mathrm{M}$ TTX, and $10 \mu \mathrm{M}$ nimodipine (Tocris Bioscience) were included in the extracellular solution. R-current density was obtained by normalizing macroscopic $\mathrm{Ba}^{2+}$ currents to cell capacitance measured at break-in. All electrophysiological experiments were obtained using a Multiclamp 700B amplifier, digitized with a Digidata 1440A, and analyzed in Clampfit (Molecular Devices) or Igor Pro (Wavemetrics).

Synaptoneurosome stimulations. Synaptoneurosome suspensions were separated into 4 tubes at $180 \mu \mathrm{l}$ each and equilibrated at $37^{\circ} \mathrm{C}$ for $10 \mathrm{~min}$. Freshly prepared ( $S$ )-3,5-dihydroxyphenylglycine (DHPG, $100 \mu \mathrm{M}$ ) was then added to synaptoneurosomes at $37^{\circ} \mathrm{C}$ for either 5 or $15 \mathrm{~min}$. Control reactions were treated in parallel under the exact same conditions but in the absence of DHPG. The reaction was stopped on ice by addition of $1 \%$ CHAPS and sonicated.

Experimental design. The $n$ values, details of controls, and comparisons used for statistical analysis are described for each experiment in the corresponding figure legend within Results. The experimenter was blinded 
A

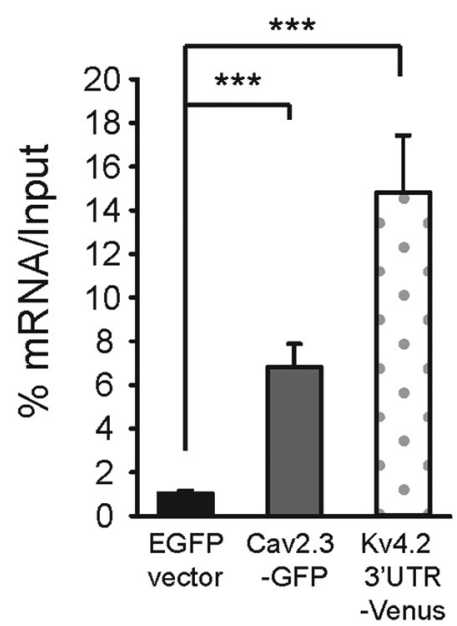

B

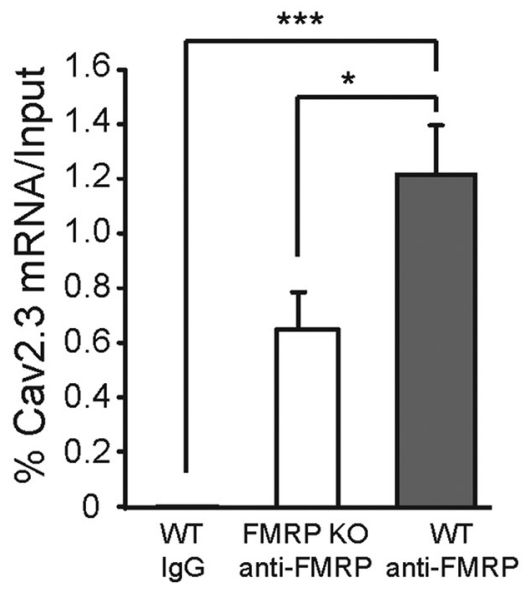

C
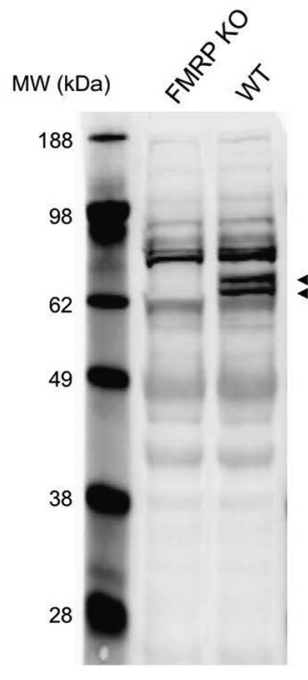

Figure 1. FMRP binds Cav2.3 mRNA in transfected HEK293 cells and in mouse brain synaptoneurosomes $\boldsymbol{A}$, FMRP RNA-IP assay results from HEK293 cells expressing FLAG-FMRP-mCherry with Cav2.3-GFP or control plasmids. Both Cav2.3-GFP mRNA and the positive control Kv4.2-3'UTR-Venus mRNA showed significant pulldown with FLAG-FMRP-mCherry compared with the negative (empty EGFP vector) control. EGFP vector, $1.0 \pm 0.13 \%$ of input; Cav2.3-GFP, $6.8 \pm 1.1 \%$ of input; Kv4.23'UTR, 14.8 $\pm 2.6 \%$ of input; $n=5, p<0.001$, one-way ANOVA. B, RNA-IP of FMRP from whole mouse brain synaptoneurosomes. The amount of Cav2.3 mRNA associated with FMRP in WT brain synaptoneurosomes (WT anti-FMRP) is significantly greater than the amount of Cav2.3 mRNA that immunoprecipitated with the FMRP antibody from FMRP KO synaptoneurosomes (FMRP K0 anti-FMRP) or when the FMRP antibody was replaced with IgG in WT samples (WT IgG). WT IgG, $0.003 \pm 0.0006 \%$ of input; WT anti-FMRP, $1.22 \pm 0.18 \%$ of input; $n=3$ and $n=5$, respectively, $p<0.001$, one-way ANOVA. FMRP K0 anti-FMRP, $0.65 \pm 0.14 \%$ of input; $n=4, p=0.02$ compared with WT anti-FMRP, one-way ANOVA. C, The specificity of the anti-FMRP antibody is shown by detection of proteins migrating at the expected molecular weight $(\sim 70-80 \mathrm{kDa}$; arrowheads) in WT but not in FMRP KO homogenates. Comparison of anti-FMRP western blots from WT and FMRP KO homogenates demonstrates FMRP antibody cross-reactivity with multiple unidentified proteins. As a result, Cav2.3 mRNA pulldown occurs in the FMRP K0 anti-FMRP samples (shown in $\boldsymbol{B}$ ) by an as yet unidentified Cav2.3 mRNA binding protein. This is consistent with previous studies using this approach (Lee et al., 2011). $A, B$, The amount of target mRNA that immunoprecipitated with FMRP was normalized against the total amount of RNA present in the input sample. $n$ values indicate the number of independent experiments. Error bars indicate mean \pm SEM. ${ }^{*} p<0.05,{ }^{* * *} p<0.001$.

to the mouse genotype for all experiments, except the synaptoneurosome stimulation, FISH, and RIP.

Statistical analysis. One-way ANOVA or, where appropriate, one-way ANOVA on ranks, was used to determine statistical significance using SigmaPlot software (Systat Software). Student-Newman-Keuls test for multiple comparisons was used for post hoc comparisons. All results are presented as the mean \pm SEM.

\section{Results}

\section{FMRP interacts with Cav2.3 mRNA}

Neurons lacking FMRP exhibit enhanced calcium spikes and dendritic excitability (Routh et al., 2013; Zhang et al., 2014), raising the possibility that FMRP might bind the mRNA of VGCCs to regulate their translation. A recent study identified the mRNA of the VGCC Cav2.3 as an FMRP target in the mouse brain (Darnell et al., 2011), although this result had not been further verified or characterized. Considering that Cav2.3 is an important regulator of dendritic calcium signaling and excitability in the CA1 region of the hippocampus (Magee and Carruth, 1999; Metz et al., 2005; Bloodgood and Sabatini, 2007; Takahashi and Magee, 2009), we sought to verify binding of FMRP to Cav2.3 mRNA. To isolate mRNAs bound to FMRP, we performed RNA-IP of FMRP from HEK293 cells expressing FLAG-FMRP-mCherry with an empty EGFP vector, Cav2.3-GFP, or Kv4.2-3'UTR-Venus. Following IP of FMRP from cell lysates, qRT-PCR was performed to analyze mRNAs that pulled down with FMRP. We found that a significant amount of Cav2.3-GFP mRNA was bound to FLAG-FMRPmCherry in lysates from cells expressing both FMRP and Cav2.3 but not from cells expressing FMRP with empty EGFP vector (Fig. 1A). As expected, the positive control Kv4.2-3'UTR mRNA bound strongly to FMRP (Gross et al., 2011; Lee et al., 2011) (Fig. 1A). We next performed RNA-IP of FMRP from whole mouse brain synaptoneurosomes from WT and FMRP KO mice and measured FMRP pulldown of endogenous Cav2.3 mRNA. We observed a significant increase in the amount of Cav2.3 mRNA associated with FMRP compared with RNA-IP performed with an IgG control in WT tissue or with the FMRP antibody in the FMRP KO (Fig. 1B). The Cav2.3 mRNA remaining in the FMRP KO samples likely results from binding to an unidentified protein that cross-reacts with the FMRP antibody as observed in previous reports (Lee et al., 2011). This is evidenced by western blot detection of a number of proteins using the FMRP antibody in lysates from FMRP KO mice (Fig. 1C). Together, our data confirm that FMRP binds Cav2.3 mRNA in both transfected HEK293 cells and in mouse brain synaptoneurosomes.

FMRP has been shown previously to regulate mRNA levels and localization by distinct mechanisms, including the stabilization of target mRNAs (PSD-95) (Zalfa et al., 2007), the repression of their translation (Kv4.2, Kv3.1, and Arc) (Strumbos et al., 2010; Lee et al., 2011; Niere et al., 2012), and the transport of mRNAs to dendritic compartments (Fmr1, CaMKII $\alpha$, and Arc) (Antar et al., 2004; Kanai et al., 2004; Dictenberg et al., 2008). Given that FMRP binds Cav2.3 mRNA, we first tested the possibility that FMRP might function to stabilize the mRNA of Cav2.3 by performing an mRNA degradation assay where mRNA levels are measured at different time points in the presence of the transcriptional inhibitor Actinomycin D (ActD, $10 \mu \mathrm{g} / \mathrm{ml}$ ). Using this approach in WT and FMRP KO hippocampal cultured neurons, we found that Cav2.3 mRNA was highly stable for up to $9 \mathrm{~h}$ in ActD and that this stability was not significantly altered in FMRP KO hippocampal neurons (Fig. 2A). In contrast, a control experiment to ensure the efficacy of transcriptional inhibition by 
A

Cav2.3 mRNA

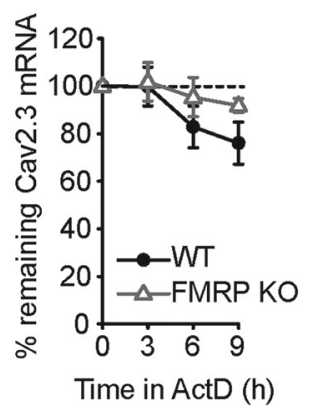

Arc mRNA

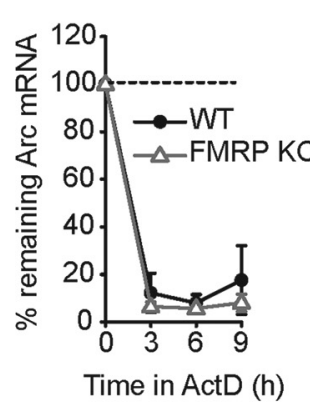

B

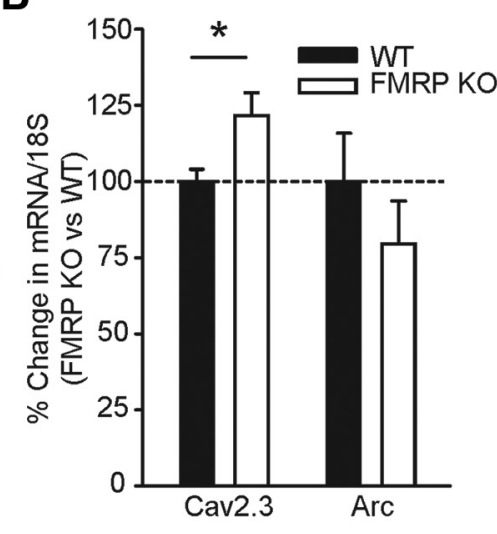

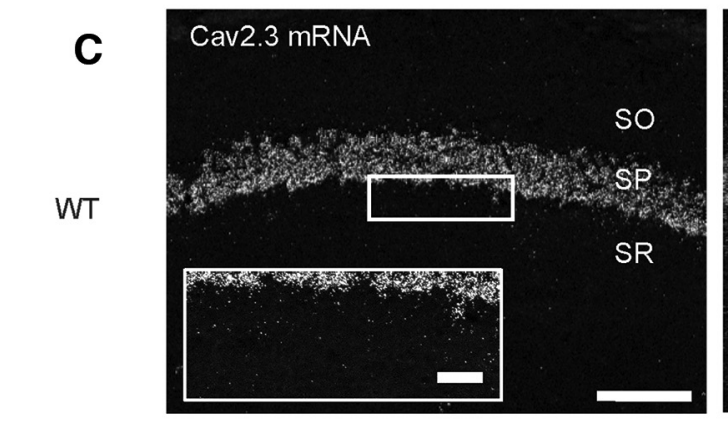
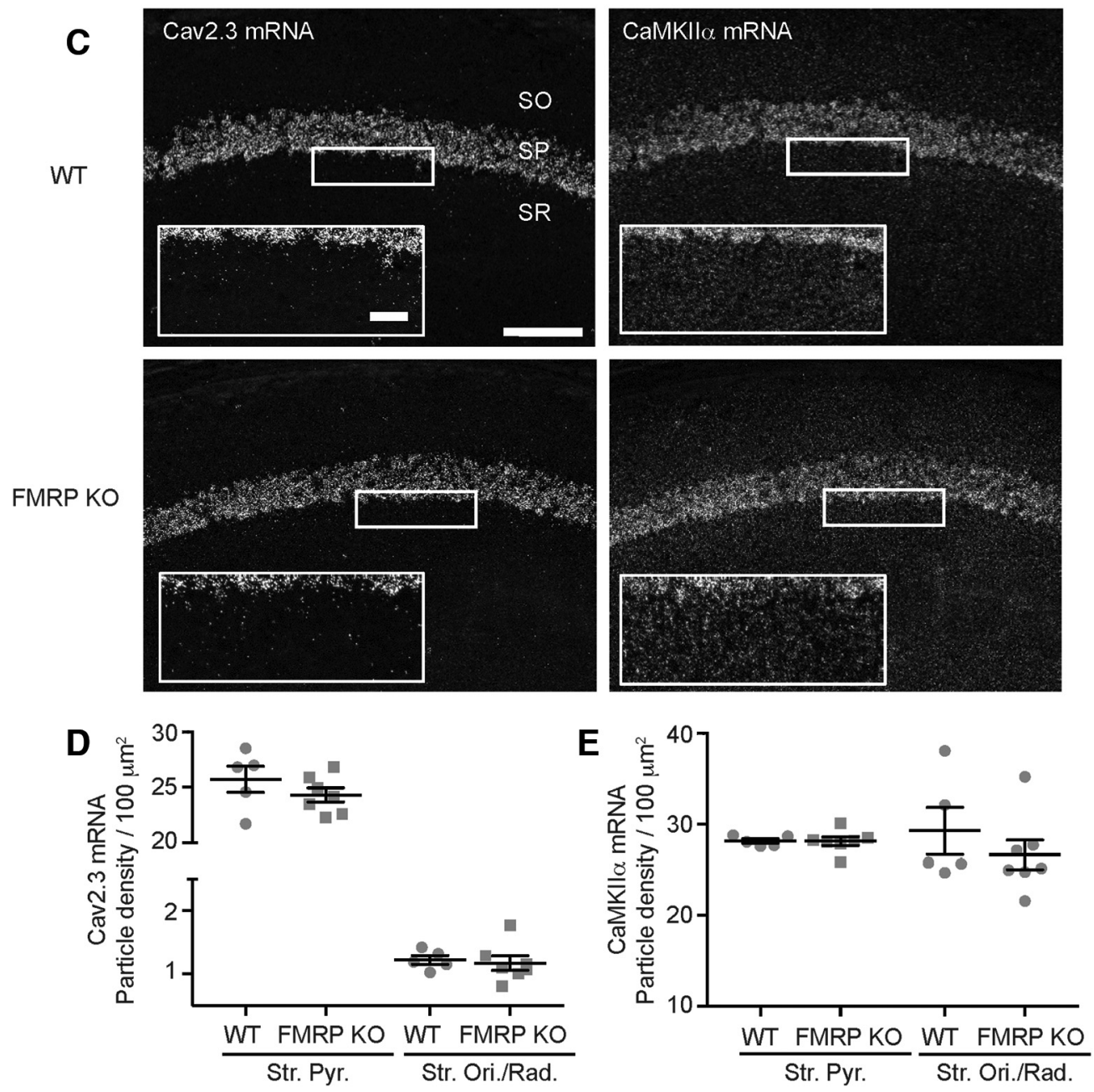

Figure 2. Basal levels of Cav2.3 mRNA are altered in FMRP KO mice without a change in mRNA stability or localization. A, qRT-PCR was performed on mRNA isolated from cultured hippocampal neurons treated with the transcriptional inhibitor ActD (10 $\mu \mathrm{g} / \mathrm{ml})$ for $0-9 \mathrm{~h}$ to measure mRNA stability. No significant differences were observed between WT and FMRP K0 in Cav2.3 mRNA at any time point. The amount of mRNA present at 3, 6, and $9 \mathrm{~h}$ in ActD was normalized against the mRNA at $0 \mathrm{~h}$. For Cav2.3: WT, $76.0 \pm 8.8 \%$ at $9 \mathrm{~h} ; \mathrm{FMRP} \mathrm{K0}, 91.8 \pm 2.9 \%$ at $9 \mathrm{~h} ; n=3, p=0.231$, one-way ANOVA. Arc mRNA is known to be highly unstable and was used as a positive indicator of ActD efficacy (Giorgi et al., 2007). For Arc: WT, 17.6 $\pm 14.5 \%$ at $9 \mathrm{~h}$; FMRP K0, 4.6 $\pm 1.6 \%$ at $9 \mathrm{~h}$, $n=3 . n$ values indicate the number of independent experiments with duplicate samples in each experiment. $\boldsymbol{B}$, Brain tissue was acutely isolated, and mRNA levels of Cav2.3 and Arc were measured by qRT-PCR. Cav2.3 mRNA is increased in the hippocampus of FMRP K0 mice compared with WT littermates with no change in the negative control, Arc mRNA (Niere et al., 2012). Cav2.3 mRNA, $121.8 \pm 7.4 \%$ of WT; $n=8, p=0.036$, one-way ANOVA. Arc mRNA: $79.5 \pm 14.0 \%$ of WT; $n=8$. C, Coronal brain sections labeled by FISH targeting Cav2.3 (left) and CaMKIl $\alpha$ (right) mRNA. The dorsal hippocampus of WT (top panels) and FMRP KO (bottom panels) mice was analyzed. Scale bar, $100 \mu \mathrm{m}$; inset, $25 \mu \mathrm{m}$. D, E, Quantification of Cav2.3 and CaMKIll $\alpha$ mRNA abundance in the pyramidal cell body layer (Str. Pyr.) and dendrite layers (Str. Ori./Rad.) showed no difference in WT versus FMRP K0. For Cav2.3 mRNA: WT Str. Pyr. and Str. Ori./Rad., $25.7 \pm 1.19$ and $1.22 \pm 0.069$ particle density $/ 100 \mu \mathrm{m}^{2}$, respectively, $n=5$; FMRP KO Str. Pyr. and Str. Ori./Rad., $24.3 \pm 0.64$ and $1.17 \pm 0.11$ particle density $/ 100 \mu \mathrm{m}^{2}$, respectively, $n=7$. For CaMKIl $\alpha \mathrm{mRNA}$ : WT Str. Pyr. and Str. Ori./Rad., $28.1 \pm 0.25$ and $29.3 \pm 2.6$ particle density/100 $\mu \mathrm{m}^{2}$, respectively, $n=5$; FMRP KO Str. Pyr. and Str. Ori./Rad., $28.1 \pm 0.47$ and $26.7 \pm 1.61$ particle density/100 $\mu \mathrm{m}^{2}$, respectively, $n=7 . B, C, n$ values indicate the number of animals used for each independent experiment. Error bars indicate mean $\pm S E M .{ }^{*} p<0.05$. 
A

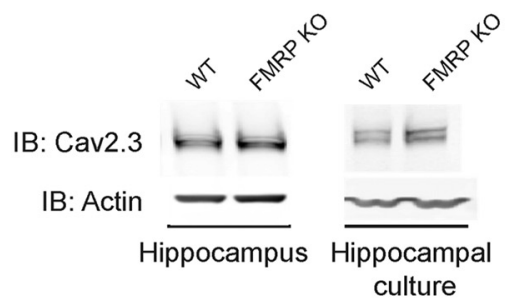

C

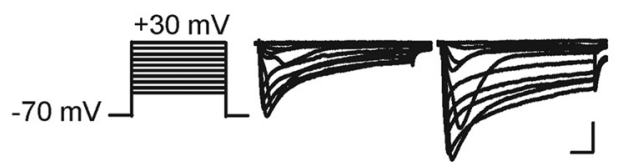

Step potential $(\mathrm{mV})$

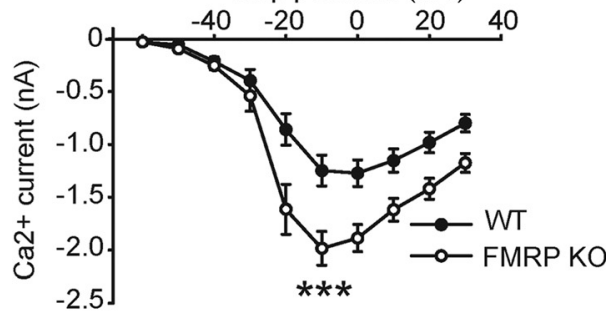

E
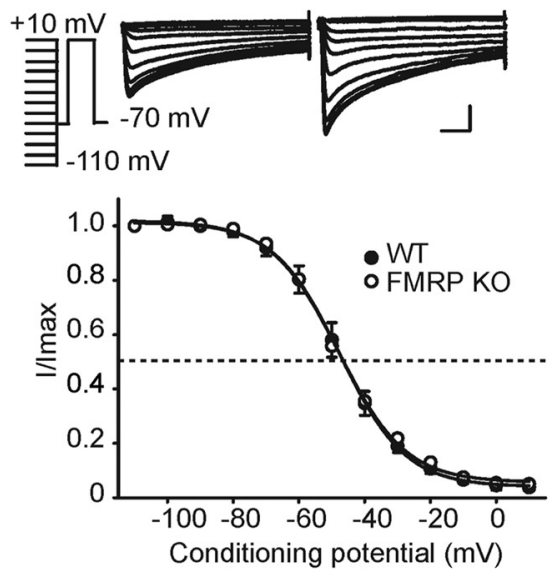

B
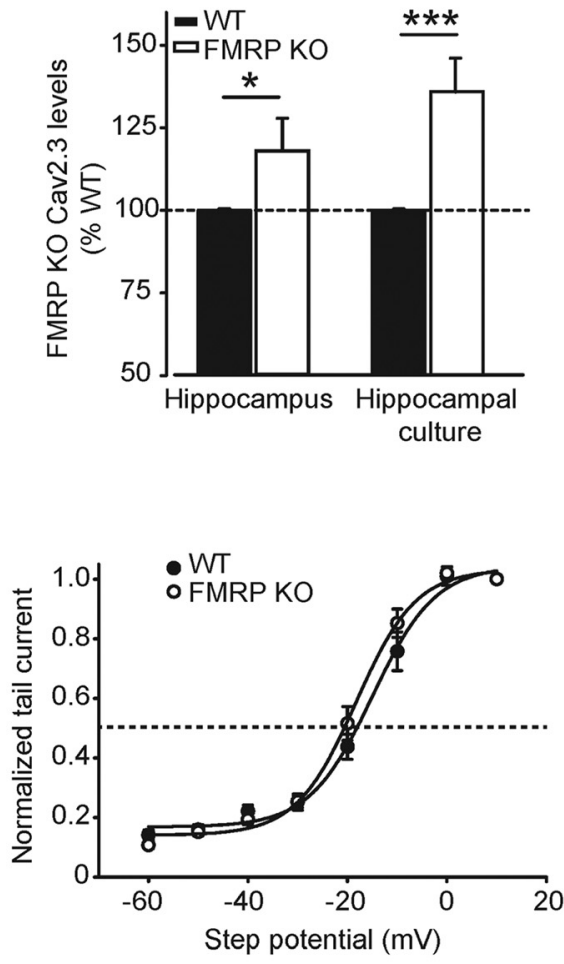

$\mathbf{F}$
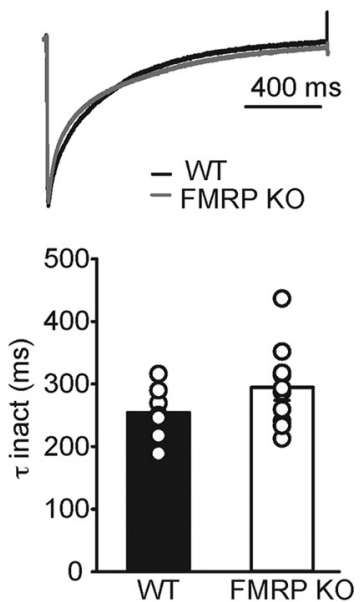

Figure 3. Cav2.3 protein levels and Cav2.3-mediated R current are enhanced in the hippocampus of FMRP KO mice $\boldsymbol{A}$, Homogenates from WT and FMRP KO neurons were probed by western blotting on hippocampal tissue (left) and from hippocampal cultured neuron DIV $20-22$ (right). The intensity of the Cav2.3 band was normalized to actin. B, Quantification shows a significant increase in Cav2.3 protein levels in FMRP KO neurons compared with WT from both hippocampal tissue and cultured neurons. In tissue, FMRP K0 was $118.0 \pm 9.9 \%$ of WT littermates; $n=7$ animals each of WT and FMRP KO, $p=0.047$, one-way ANOVA. In culture, FMRP KO was $136.0 \pm 10.3 \%$ of WT, $n=12$ replicates from 6 independent culture preparations, $p=0.002$, one-way ANOVA. $C-\boldsymbol{F}$, Whole-cell voltage-clamp electrophysiology from cultured hippocampal neurons showed an increase in the amplitude of $R$ current in the FMRP K0 without a change in channel properties. The charge carrier was $2 \mathrm{~mm} \mathrm{Ca}^{2+}$.C, Neurons were held at $-70 \mathrm{mV}$, and voltage steps were performed to generate an $/-V$ curve. WT, $-1.25 \pm 0.15 \mathrm{nA}$ at $-10 \mathrm{mV} ;$ FMRP K0, $-1.98 \pm 0.16 \mathrm{nA}$ at $-10 \mathrm{mV}$; $n=24$ and $n=25$ cells, respectively, from 5 independent culture preparations, $p=0.001$, one-way ANOVA. $\boldsymbol{D}$, Voltage dependence of activation was determined by analyzing the peak of the tail current in C and was $V_{50}=-17.3 \pm 1.6 \mathrm{mV}$ for WT and $V_{50}=-19.2 \pm 1.1 \mathrm{mV}$ for FMRP KO. $\boldsymbol{E}$, $F$, Steady-state inactivation and time constant of inactivation $\left(\tau_{\text {inact }}\right)$ were not altered between WT and FMRP KO neurons. For steady-state inactivation: WT, $V_{50}=-46.5 \pm 2.4 \mathrm{mV}(n=6)$; FMRP KO, $V_{50}=-46.3 \pm 1.5 \mathrm{mV}(n=10)$. $\boldsymbol{F}$, The $\tau_{\text {inact }}$ was obtained by fitting the decaying phase of the current at $10 \mathrm{mV}$ with a single exponential and was $253.9 \pm 16.2 \mathrm{~ms}(n=7)$ for WT and $294.6 \pm 20.8 \mathrm{~ms}(n=10)$ for FMRP KO. Calibration: $C, E, 500 \mathrm{pA}, 50 \mathrm{~ms}$. Error bars indicate mean \pm SEM. ${ }^{*} p<0.05,{ }^{* * *} p<0.005$.

ActD showed that Arc mRNA was rapidly degraded (Giorgi et al., 2007) (Fig. 2A). Next, we performed qRT-PCR on cell lysates isolated from hippocampal tissue and compared total Cav2.3 mRNA levels in WT and FMRP KO mice. If FMRP acts to stabilize this mRNA, we would expect a decrease in Cav2.3 mRNA levels in the absence of FMRP. However, we found that Cav2.3
mRNA levels were significantly enhanced in FMRP KO relative to WT mice (Fig. 2B). These data suggest that, although FMRP binds to and regulates Cav2.3 mRNA abundance in the hippocampus, it does not affect Cav2.3 mRNA stability.

To assess the localization of Cav2.3 mRNA in WT and FMRP $\mathrm{KO}$ mice, we performed FISH on hippocampal sections and im- 
A

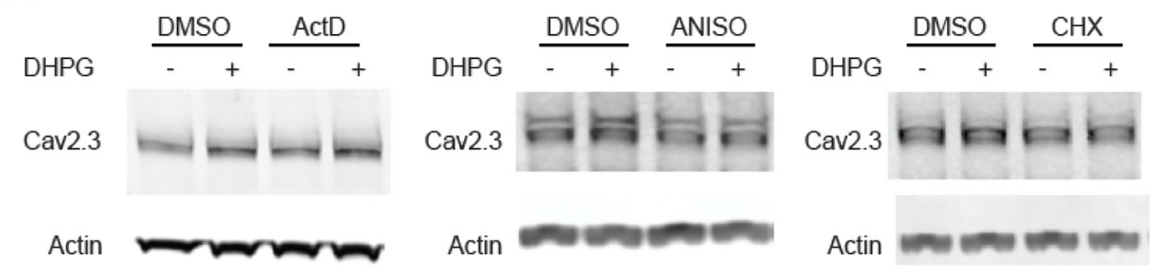

B
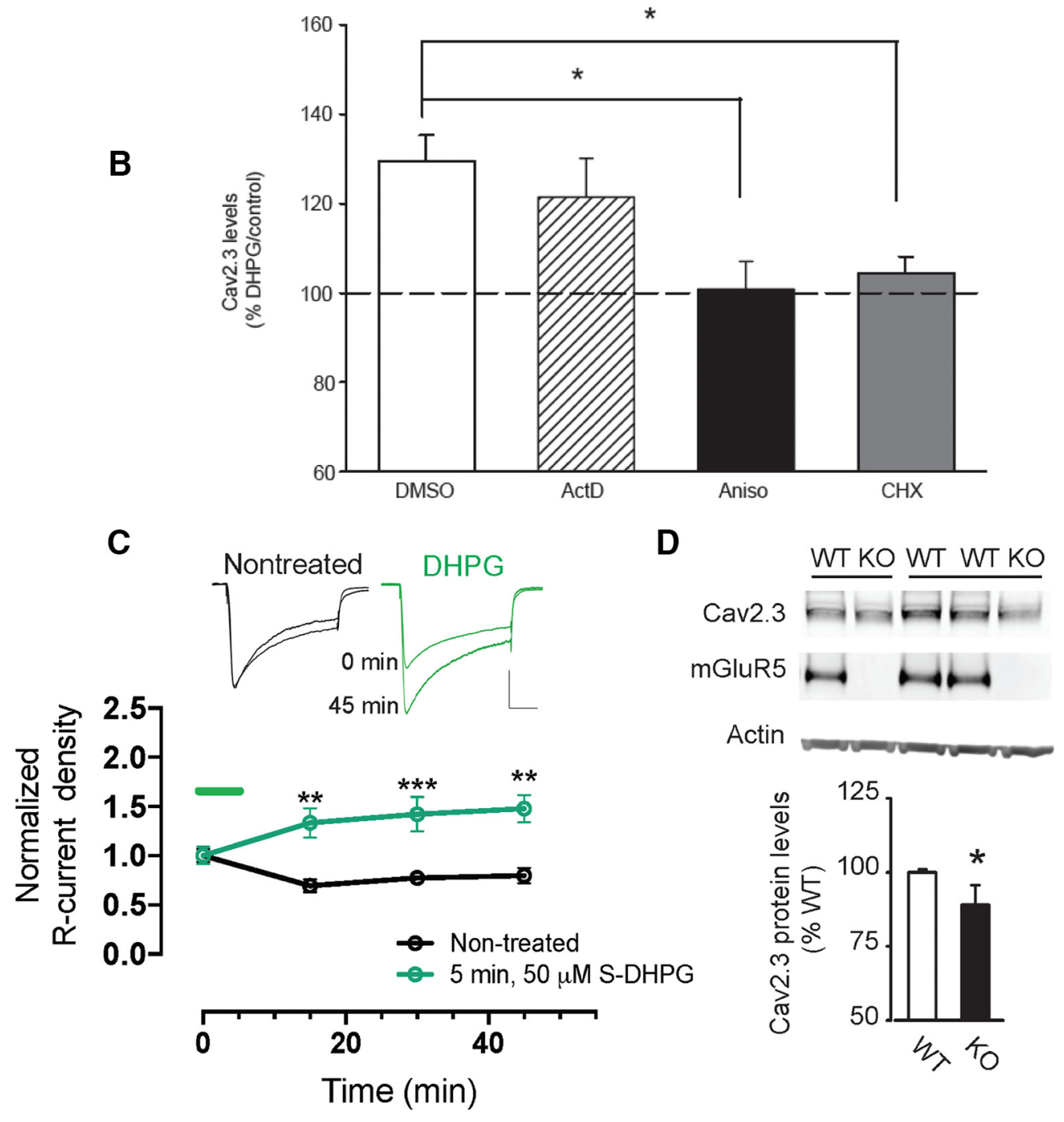

Figure 4. Gpl mGluR stimulation regulates peak R-current density and Cav2.3 channel expression. $A$, Representative western blots from cultured hippocampal neurons that were preincubated with $10 \mu \mathrm{g} / \mathrm{ml} \mathrm{ActD,} 20 \mu \mathrm{m}$ Aniso, $50 \mu \mathrm{m}$ CHX, or DMSO vehicle (0.1\%) before stimulation with DHPG for 5 min with a 25 min wash. $\boldsymbol{B}$, Quantification of $\boldsymbol{A}$. DHPG-induced increases in Cav2.3 protein are blocked in the translational inhibitors Aniso and CHX but not in the transcriptional blocker ActD compared with vehicle control. The Cav2.3 bands were normalized to actin. DMSO, $129.5 \pm 5.9 \%$ of control; Aniso, $100.8 \pm 6.2 \%$ of control; $n=7$ experiments from 3 independent culture preparations, $p=0.036$, one-way ANOVA; CHX, 104.4 $\pm 3.6 \%$ of control; $n=5$ experiments from 3 independent culture preparations, $p=0.022$, one-way ANOVA; $A c t D, 121.4 \pm 8.6 \%$ of control; $n=7$ experiments from 3 independent culture preparations. Error bars indicate mean \pm SEM. ${ }^{*} p<$ 0.05. C, Cultured rat hippocampal neurons were treated with a single 5 min application of the Gpl mGluR agonist S-DHPG ( $50 \mu \mathrm{M}$ ). DHPG treatment (green) upregulated peak R-current density relative to nontreated control (black) neurons (top). Peak current density, binned at 15 min intervals after treatment, are shown for each time point (bottom). Comparison of DHPG to nontreated control neurons yielded significantly elevated R-current density at all time points after treatment (bottom). Nontreated: $79.7 \pm 0.22 \%$ of pretreatment control 45 min after treatment; $n=7-14$. DHPG treated: $147.8 \pm 0.50 \%$ of pretreatment control 45 min after treatment; $n=10-15 .{ }^{* *} p<0.01$ (two-way ANOVA). ${ }^{* * *} p<0.001$ (two-way ANOVA). Calibration: 10 pA/pF, 200 ms, $D$, Western blots of hippocampal tissue from mGluR5 K0 mice showed significantly less Cav2.3 protein in mice lacking mGluR5 compared with WT littermates. mGluR5 K0 levels were $88.9 \pm 6.7 \%$ of WT control, $n=4$ WT and $n=5$ mGluR5 K0 animals, $p=0.029$, one-way ANOVA. Error bars indicate mean \pm SEM, ${ }^{*} p<0.05$.

aged Cav2.3 mRNA in the soma and dendrites of CA1 pyramidal neurons. We observed clear somatic and dendritic localization of Cav2.3 mRNA in WT hippocampus (Fig. 2C,D). FMRP KO showed similar levels of Cav2.3 mRNA in both hippocampal subregions (Fig. 2C,D), indicating that, although Cav2.3 mRNA is present in dendrites, its localization under steady-state conditions does not seem to depend on FMRP. This is similar to what has been shown for other FMRP targets, including Kv4.2, PSD95, and CaMKII $\alpha$ (Zalfa et al., 2007; Dictenberg et al., 2008; Lee et al., 2011). As expected from previous studies (Zalfa et al., 2007; 
A

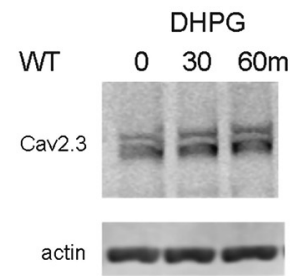

FMRP KO

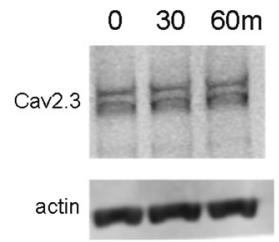

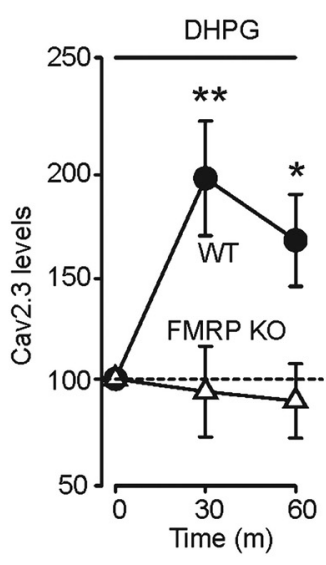

B

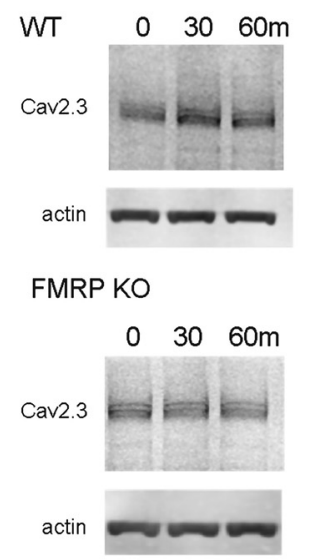

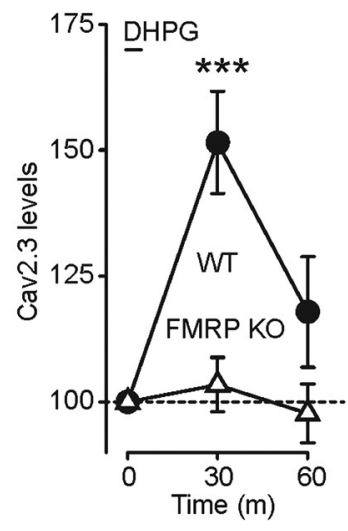

Figure 5. Gpl mGluR stimulation increases Cav2.3 translation in hippocampal cultured neurons from WT but not FMRP KO mice. $\boldsymbol{A}, \boldsymbol{B}$, Cultured hippocampal neurons were stimulated with $100 \mu \mathrm{m}$ DHPG either $(\boldsymbol{A})$ chronically for 30 or $60 \mathrm{~min}$ or $(\boldsymbol{B})$ transiently for $5 \mathrm{~min}$ followed by a wash for 25 or $55 \mathrm{~min}$. Both of these conditions resulted in a significant increase in Cav2.3 protein levels at $30 \mathrm{~min}$ in WT cultures, and the enhancement persisted at $60 \mathrm{~min}$ after chronic $(\boldsymbol{A})$ but not transient $(\boldsymbol{B})$ exposure. Neurons cultured from FMRP K0 mice did not show any change in Cav2.3 protein levels above control in response to chronic or transient DHPG application. Chronic DHPG: WT, $193.5 \pm 26.7$ of control at $30 \mathrm{~min}, p=0.006$, one-way ANOVA; $164.7 \pm 21.5 \%$ of control at 60 min, $p=0.025$, one-way ANOVA; $n=7$ experiments from 4 independent culture preparations; FMRP K0, $94.0 \pm 21.1 \%$ of control at $30 \mathrm{~min} ; 89.6 \pm 17.4 \%$ of control at 60 min, $n=5$ experiments from 4 independent culture preparations. Transient DHPG: WT, $151.5 \pm 10.2 \%$ of control at $30 \mathrm{~min}, p<0.001$, one-way ANOVA; $117.9 \pm 11.0 \%$ of control at 60 min, $p=0.184$, one-way ANOVA; $n=$ 12 experiments from 6 independent culture preparations; FMRP KO, $103.4 \pm 5.4 \%$ of control at $30 \mathrm{~min}, 97.7 \pm 5.8 \%$ of control at $60 \mathrm{~min} ; n=12$ experiments from 6 independent culture preparations. Error bars indicate mean \pm SEM, ${ }^{*} p<0.05,{ }^{* *} p<0.01,{ }^{* * *} p<0.001$.

Dictenberg et al., 2008), our analysis of CaMKII $\alpha$ mRNA localization did not show a difference between WT and FMRP KO (Fig. 2C,E). Together, our data show that FMRP KO mice exhibit a small increase in total hippocampal Cav2.3 mRNA but maintain normal Cav2.3 mRNA stability and localization.

\section{Cav2.3 expression is regulated by FMRP}

We next investigated the possibility that FMRP represses basal Cav2.3 translation. Western blots performed from tissue acutely isolated from the hippocampus of FMRP KO mice showed that Cav2.3 protein levels were significantly enhanced compared with WT (Fig. $3 A, B$, left). Additionally, when probing cultured hippocampal neuron homogenates, we found that Cav2.3 protein levels were similarly enhanced in the FMRP KO (Fig. $3 A, B$, right). To determine whether FMRP regulated the degradation of Cav2.3 protein, we incubated cultured hippocampal neurons in either vehicle (0.1\% DMSO) or the proteasome blocker MG132 (10 $\mu \mathrm{M}, 90 \mathrm{~min}$ ) and found no difference in Cav2.3 protein accumulation in FMRP KO compared with WT neurons treated with MG132 (WT, $111.0 \pm 8.6 \%$ of DMSO control; FMRP KO, $111.2 \pm 4.8 \%$ of DMSO control; $n=4$, data not shown). Thus, in the absence of FMRP, hippocampal neurons have increased basal levels of Cav2.3 protein that likely result from a loss of FMRPdependent translational repression.

To determine whether the increase in Cav2.3 protein functionally affects the physiology of neurons lacking FMRP, we performed whole-cell voltage-clamp recordings of cultured hippocampal neurons to measure Cav2.3-mediated $\mathrm{R}$ current. R-type calcium channel current-voltage curves in neurons from both WT and FMRP KO cultures revealed that FMRP KO neurons exhibited a dramatic increase in peak $\mathrm{R}$ current compared with WT neurons (Fig. 3C). The enhanced R current appears to be due to increased channel expression, as we found no changes in the voltage dependence of channel activation, steady-state inactivation, or time constant of inactivation (Fig. $3 D, F$ ). FMRP $\mathrm{KO}$ neurons therefore have an increase in Cav2.3 protein that functionally results in an increase in Cav2.3-mediated R current.

\section{Group I mGluRs regulate Cav2.3 translation}

Our data demonstrate that FMRP binds to Cav2.3 mRNA and regulates its expression under basal conditions; we next sought to investigate whether FMRP has a role in activity-dependent modulation of Cav2.3. It is well documented that FMRP is important for regulating protein translation downstream of GpI mGluR activation, where signaling via these receptors leads to the dephosphorylation of FMRP and release of its repression on translation of target mRNAs (Waung and Huber, 2009). To address whether GpI mGluRs regulate Cav2.3 protein levels in neurons, we applied the GpI mGluR agonist RS-DHPG (100 $\mu \mathrm{M})$ to cultured WT mouse hippocampal neurons using a standard mGluRLTD induction protocol (Snyder et al., 2001) consisting of a 5 min DHPG stimulation followed by a $25 \mathrm{~min}$ wash. We found a significant increase in the amount of Cav2.3 protein in response to DHPG (Fig. 4A,B; DMSO (-/+)). As GpI mGluR activation could increase Cav2.3 protein levels by using transcription and/or translation pathways, we applied DHPG in the presence of either the transcriptional blocker ActD $(10 \mu \mathrm{g} / \mathrm{ml}$, pretreated 15 $\mathrm{min}$ ) or the translational inhibitors anisomycin (Aniso, $20 \mu \mathrm{M}$, pretreated $30 \mathrm{~min}$ ) and cycloheximide ( $\mathrm{CHX}, 50 \mu \mathrm{M}$, pretreated 5 min). While there was no significant effect of ActD on DHPGinduced increases in Cav2.3, both Aniso and CHX effectively blocked any change in Cav2.3 protein levels (Fig. 4A,B).

To determine whether GpI mGluR regulation of Cav2.3 translation corresponded to changes in functional $\mathrm{R}$ current mediated by Cav2.3, we measured peak R current magnitude after DHPG treatment in cultured rat hippocampal neurons. A single $5 \mathrm{~min}$ S-DHPG $(50 \mu \mathrm{M})$ treatment upregulated R-current density compared with nonstimulated neurons (Fig. 4C). In addition, Cav2.3 protein levels were significantly reduced in hippocampal tissue from mGluR5 KO mice compared with WT littermates (Fig. 4D), providing evidence that basal mGluR5 signaling is required to maintain Cav2.3 protein levels. These data suggest that Cav2.3 is translated and expressed downstream of GpI mGluR stimulation, supporting a possible role for activity-dependent regulation by FMRP. 
A

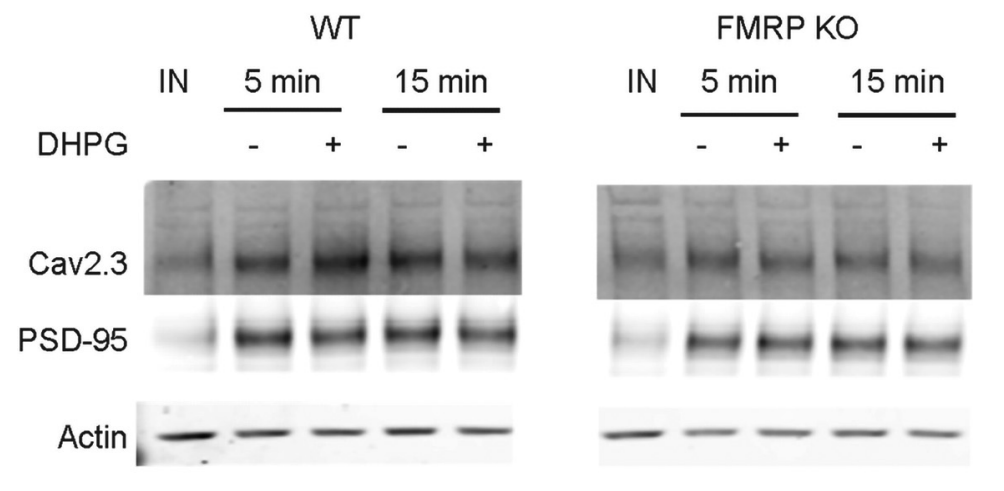

B

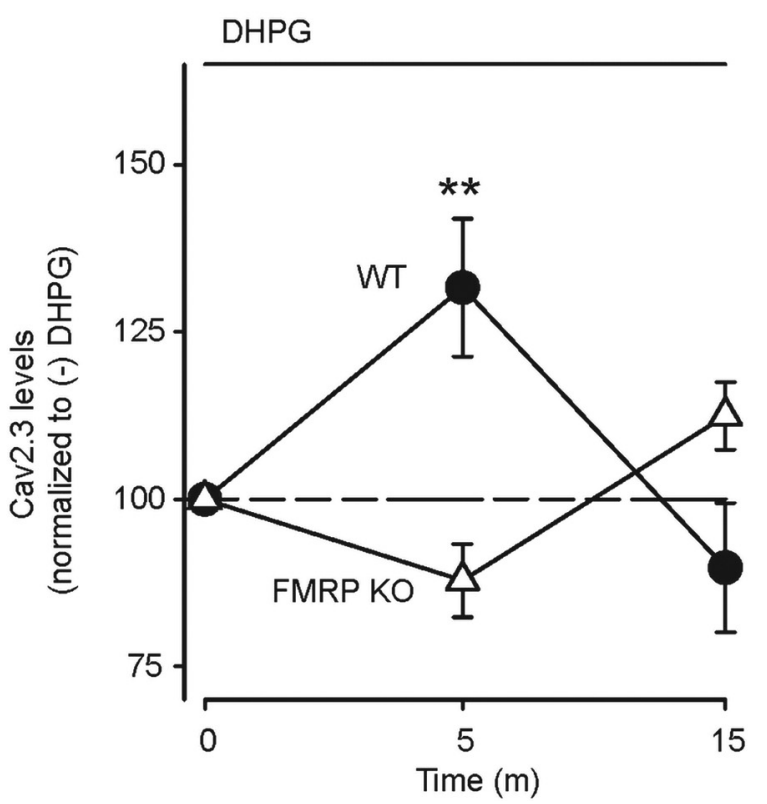

Figure 6. Gpl mGluR stimulation increases Cav2.3 in hippocampal synaptoneurosomes from WT but not FMRP KO mice. $\boldsymbol{A}$, Representative western blots from synaptoneurosomes that were acutely isolated from hippocampal tissue and incubated at $37^{\circ} \mathrm{C}$ for 5 or 15 min in either the presence (+) or absence $(-)$ of $100 \mu \mathrm{m}$ DHPG. Input samples (IN) were loaded and PSD-95 levels measured to ensure effective isolation of synaptoneurosomes. $\boldsymbol{B}$, Quantification of $\boldsymbol{A}$. DHPG stimulation increased levels of Cav2.3 protein in WT but not FMRP KO synaptoneurosomes at the 5 min time point. The Cav2.3 bands were normalized to actin, and the DHPG-stimulated samples were expressed as the percentage change in Cav2.3 compared with unstimulated samples at the same time point. WT: $131.6 \pm 10.3 \%$ of control at $5 \mathrm{~min}, 89.7 \pm 9.7 \%$ of control at $15 \mathrm{~min} ; n=8$ animals, $p=0.009$ at $5 \mathrm{~min}$, one-way ANOVA. FMRP K0: $87.8 \pm 5.5 \%$ of control at $5 \mathrm{~min}, 112.5 \pm 5.0 \%$ of control at $15 \mathrm{~min} ; n=5$ animals. Error bars indicate mean \pm SEM. ${ }^{* *} p<0.01$.

\section{Group I mGluR regulation of Cav2.3 expression requires FMRP}

Given that GpI mGluR activation increases Cav2.3 protein abundance via translation of preexisting mRNAs (Fig. $4 A, B$ ), we next investigated the possibility that FMRP serves as the link between receptor activation and changes in Cav2.3 protein levels. To address whether GpI mGluR regulation of Cav2.3 translation functions through FMRP in neurons, we applied the GpI mGluR agonist RS-DHPG $(100 \mu \mathrm{M})$ to cultured WT and FMRP KO mouse hippocampal neurons for 30 or $60 \mathrm{~min}$ and measured changes in Cav2.3 protein levels by western blot. We found a striking and persistent increase in the amount of Cav2.3 protein following chronic application of DHPG (Fig. 5A). Conversely, neurons lacking FMRP did not show an increase in Cav2.3 protein levels following chronic DHPG application (Fig. 5A). Alternatively, using the mGluR-LTD induction protocol above,
DHPG was applied for $5 \mathrm{~min}$ followed by a 25 or 55 min wash. The mGluR-LTD protocol upregulated Cav2.3 protein expression at $30 \mathrm{~min}$, which tapered off by 60 min (Fig. 5B). Much like chronic DHPG application, mGluR-LTD was unable to stimulate Cav2.3 translation in FMRP KO neurons (Fig. 5B). Together, GpI mGluR stimulation elicits a more stable increase in Cav2.3 protein, whereas an LTD-like stimulus leads to a more transient burst of Cav2.3 expression.

FMRP has been shown to regulate local translation of target mRNA in subcellular compartments, such as dendritic spines (Muddashetty et al., 2007; Ifrim et al., 2015). To determine whether GpI mGluRdependent FMRP regulation of Cav2.3 translation can occur locally at synapses, we first isolated synaptic compartments from WT and FMRP KO mouse hippocampal tissue using a synaptoneurosome preparation. The synaptoneurosomes were then stimulated with DHPG (100 $\mu \mathrm{M}$ S-DHPG) for 5 or $15 \mathrm{~min}$, and Cav2.3 protein levels were measured by western blot. Cav2.3 expression was significantly elevated at $5 \mathrm{~min}$ and returned to control levels by $15 \mathrm{~min}$ in WT synaptoneurosomes (Fig. 6A,B). This sharply contrasts with our findings from synaptoneurosomes isolated from FMRP KOs, where DHPG stimulation at both time points showed no significant change in Cav2.3 protein levels compared with control (Fig. $6 A, B)$. Together, our data show that GpI mGluR signaling uses FMRP to induce local translation of preexisting Cav2.3 mRNAs at the synapse.

\section{Discussion}

Neurons from animal models of FXS show profound alterations in dendritic excitability and calcium spiking, which may underlie the hyperexcitability seen in patients suffering from the disease (Contractor et al., 2015). Thus, identifying ion channels targeted by FMRP that may be aberrantly expressed in FXS provides novel avenues for future therapeutic strategies. Here we report that FMRP binds the mRNA of the dendritic Cav2.3, represses its translation under basal conditions and, following GpI mGluR stimulation, FMRP releases this translational repression to increase Cav2.3 protein expression (Fig. 7). FMRP KO mice lack this regulation, exhibiting exaggerated steady-state Cav2.3 protein levels and a failure to increase Cav2.3 protein levels following GpI mGluR stimulation (Fig. 7). This study is the first to demonstrate both the steadystate upregulation and the loss of activity-dependent expression of a VGCC in a mouse model of FXS.

FMRP binds Cav2.3 mRNAs and represses their translation FMRP is emerging as a critical regulator of protein expression in development, plasticity, and disease, and extensive efforts are un- 
derway to identify and characterize FMRP target mRNAs (Richter et al., 2015). In our study, we expanded upon the recent finding (Darnell et al., 2011) that FMRP binds Cav2.3 mRNA by performing RNA-IP in two systems. First, we showed that FMRP binds Cav2.3 when overexpressed in HEK293 cells using a Cav2.3 construct that contains the entire coding region and a small portion of the $3^{\prime}$ UTR. Within these regions, there are many putative FMRP binding sites called "Gquartets" (Schaeffer et al., 2001; Menon et al., 2008; Darnell et al., 2011), and FMRP likely interacts with Cav2.3 mRNA at one or several of these sites (Darnell et al., 2011). Next, our data show that FMRP binds Cav2.3 mRNA in isolated synaptoneurosomes from mouse brain, suggesting that FMRP could regulate local expression of Cav2.3 at synapses. FMRP is found at dendrites and spines (Antar et al., 2004) where it has been shown to bind and repress the local translation of mRNAs important for synaptic development and plasticity, such as Arc and PSD-95 (Muddashetty et al., 2007; Niere et al., 2012; Ifrim et al., 2015); however, our study is the first to show FMRP binding to the mRNA of a VGCC at synapses.

Once bound to its target mRNA, FMRP can enhance mRNA stability (Zalfa et al., 2007) or repress mRNA translation (Zalfa et al., 2003; Muddashetty et al., 2007; Lee et al., 2011). Evidence suggests that binding of FMRP represses translation by stalling polyribosome advancement during elongation (Darnell et al., 2011) and loss of FMRP leads to exaggerated translation of target mRNAs. Our data agree with this model of FMRPdependent repression of translation, as we found that neurons from FMRP KO mice showed no alterations in Cav2.3 mRNA stability while exhibiting an increase in Cav2.3 protein levels and Cav2.3-mediated currents.

FMRP can also regulate ion channel function and surface expression by direct protein-protein interactions, independently of its traditional role in translational regulation (Brown et al., 2010; Deng et al., 2013; Ferron et al., 2014; Myrick et al., 2015). For instance, the VGCC Cav2.2 protein directly interacts with FMRP in the presynaptic terminal of DRG neurons, and this leads to a downregulation of surface expression of the channel (Ferron et al., 2014). This is thought to occur via FMRP-dependent targeting of the channel for degradation. Our observed increase in Cav2.3 protein and Cav2.3-mediated currents could also be explained by a similar mechanism, whereby loss of FMRP would lead to a reduction in Cav2.3 degradation and an accumulation of Cav2.3 protein. Our data do not rule out this possibility, although we did not see an effect on Cav2.3 proteasomal degradation in FMRP KO neurons. Our results suggest that a translation-dependent mechanism is a much stronger possibility.

A

B

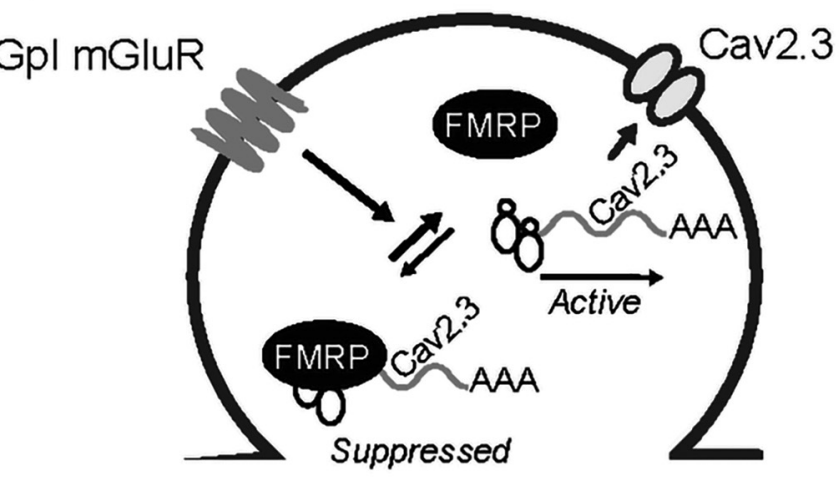

\section{FMRP KO}

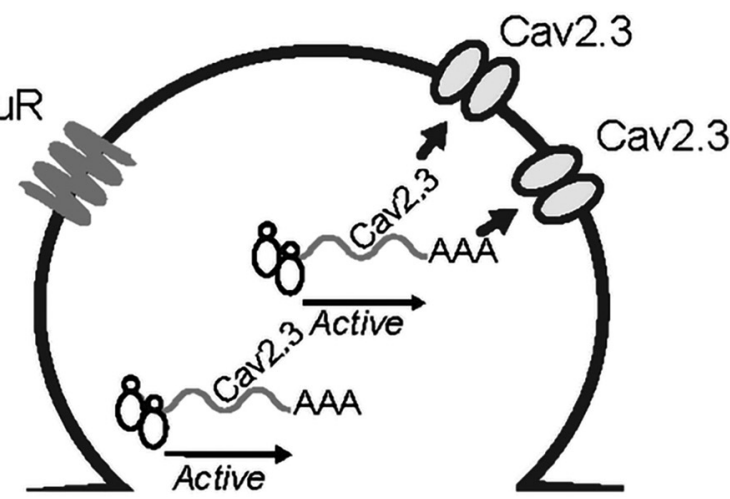

Figure 7. Working model of FMRP's regulation of Cav2.3 translation. $A$, In WT mice, FMRP binds Cav2.3 mRNA and functions to suppress its translation in dendrites under basal conditions (Figs. 1,3). Activation of Gpl mGluRs relieves FMRP-dependent supleads to elevated steady-state levels of Cav2.3 in the plasma membrane (Fig. 3). Gpl mGluR stimulation can no longer regulate Cav2.3 translation in the absence of FMRP (Figs. 5, 6).

\section{Loss of GpI mGluR-mediated Cav2.3 expression in FMRP KO neurons}

In addition to changes in basal levels of Cav2.3 protein, our data show a loss of regulated Cav2.3 expression following activation of GpI mGluRs in neurons from FMRP KO mice. The GpI mGluRdependent increase in Cav2.3 protein seen in WT neurons requires translation and occurs in isolated synaptoneurosomes. This supports the idea that FMRP normally functions to suppress Cav2.3 translation under basal conditions while providing evidence that GpI mGluR activation relieves FMRP's translational repression to increase Cav2.3 protein levels. Other FMRP targets, such as PSD-95 and Arc, also use this mechanism to achieve regulated translation downstream of $\mathrm{GpI}$ mGluR activation (Muddashetty et al., 2007; Niere et al., 2012; Ifrim et al., 2015). It is postulated that, in the absence of FMRP, basal translation of these target mRNAs is exaggerated and GpI mGluR activation no longer controls their expression, leading to alterations in synaptic function and enhanced mGluR-LTD that does not require translation (Hou et al., 2006; Nosyreva and Huber, 2006). This enhanced translation-independent mGluR-LTD in the FMRP KO suggests that the exaggerated expression of target proteins under basal conditions is sufficient to maintain persistent synaptic de- 
pression. Loss of this mGluR-dependent translation and plasticity is thought to contribute to the etiology of FXS (Bear et al., 2004). Our study aligns well with this model as we show that FMRP KO mice have enhanced Cav2.3 basal expression (Fig. 3) and a loss of GpI mGluR-dependent increases in Cav2.3 protein (Figs. 5, 6). Together, it is possible that the loss of regulated Cav2.3 translation may play a role in the enhanced mGluR-LTD observed in FMRP KO mice.

\section{A potential role for Cav2.3 in mGluR-LTD}

Our study shows that Cav2.3 translation is upregulated in response to GpI mGluR activation in cultured hippocampal neurons and isolated synaptoneurosomes. This provides the first evidence that Cav2.3 is translated downstream of GpI mGluR activation and that this may be important for the maintenance of mGluR-LTD. A previous study has shown that mGluR-LTD is blocked in the presence of the Cav2.3 antagonist $\mathrm{Ni}^{2+}$ (Oliet et al., 1997). At that time, this was interpreted as a requirement for T-type VGCCs in mGluR-LTD, as application of $\mathrm{Ni}^{2+}$ will inhibit both Cav2.3 and T-type channels (Williams et al., 1994; Zamponi et al., 1996; Lee et al., 1999). While our study does not exclude the possibility that T-type channels are important for mGluR-LTD, regulation of Cav2.3 expression in response to an mGluR-LTD induction stimulus suggests a role for Cav2.3 in this form of plasticity. It is possible that an increase in the abundance of Cav2.3 may contribute to the enhanced dendritic excitability seen following GpI mGluR activation (Desai and Conn, 1991; Gereau and Conn, 1995). Indeed, it has been shown that local stimulation of GpI mGluRs in the CA1 region of the hippocampus upregulates Cav2.3mediated currents, leading to increased neuronal excitability by switching the postburst afterhyperpolarization to an afterdepolarization (Park et al., 2010; Park and Spruston, 2012). Several other factors underlie the changes in excitability following GpI mGluR stimulation, including the downregulation of several potassium conductances (Charpak et al., 1990; Desai and Conn, 1991; Gereau and Conn, 1995; Brager et al., 2012), and more work is needed to determine the contribution of Cav2.3.

\section{Cav2.3 and FXS}

FMRP KO mice exhibit enhanced neuron and circuit-level hyperexcitability that likely results from the loss of FMRPdependent regulation of dendritic ion channels (Brager et al., 2012; Routh et al., 2013; Zhang et al., 2014). FMRP controls the expression and/or activity of several potassium channels, including Kv4.2, HCN1, BK, and SK channels (Gross et al., 2011; Lee et al., 2011; Brager et al., 2012; Deng et al., 2013, 2019; Zhang et al., 2014), and the downregulation of these channels in FMRP KO mice is thought to enhance dendritic excitability and contribute to cognitive impairments seen in FXS (Contractor et al., 2015).

In addition to enhanced intrinsic excitability, several laboratories have observed an increase in the amplitude of dendritic calcium spikes in FMRP KO mice (Routh et al., 2013; Zhang et al., 2014). This could be due to the increase in Cav2.3-mediated currents reported in our study. Dendritic Cav2.3 channels generate large calcium spikes in response to both back-propagating action potentials and synaptic activity (Bloodgood and Sabatini, 2007) and regulate intrinsic excitability by altering action potential burst firing, postburst afterdepolarizations, and plateau potentials (Magee and Carruth, 1999; Metz et al., 2005; Takahashi and Magee, 2009). Given the channel's role in modulating excitability, Cav2.3 has emerged as an effective target of various antiepileptic drugs (Hainsworth et al., 2003; Kuzmiski et al., 2005), and Cav2.3 KO animals show a reduction in seizure susceptibility (Weiergräber et al., 2006, 2007). Given the ability of Cav2.3 to influence neuronal firing, calcium signaling, and seizure susceptibility, our observed increase in Cav2.3-mediated currents in FMRP KO neurons likely impacts both dendritic excitability and calcium spiking, contributing to the hyperexcitability seen in mouse models of FXS. Our study, combined with other recent work (for summary, see Contractor et al., 2015) suggests that therapeutics that alter the activity or expression of voltage-gated ion channels, including Cav2.3, have the potential to treat cognitive impairments associated with FXS, such as hyperactivity, seizures, and sensory hypersensitivity.

\section{References}

Antar LN, Afroz R, Dictenberg JB, Carroll RC, Bassell GJ (2004) Metabotropic glutamate receptor activation regulates fragile $\mathrm{x}$ mental retardation protein and FMR1 mRNA localization differentially in dendrites and at synapses. J Neurosci 24:2648-2655.

Bear MF, Huber KM, Warren ST (2004) The mGluR theory of fragile X mental retardation. Trends Neurosci 27:370-377.

Bloodgood BL, Sabatini BL (2007) Nonlinear regulation of unitary synaptic signals by $\mathrm{CaV}(2.3)$ voltage-sensitive calcium channels located in dendritic spines. Neuron 53:249-260.

Brager DH, Akhavan AR, Johnston D (2012) Impaired dendritic expression and plasticity of h-channels in the $\mathrm{fmr} 1(-/ \mathrm{y})$ mouse model of fragile $\mathrm{X}$ syndrome. Cell Rep 1:225-233.

Brown MR, Kronengold J, Gazula VR, Chen Y, Strumbos JG, Sigworth FJ, Navaratnam D, Kaczmarek LK (2010) Fragile X mental retardation protein controls gating of the sodium-activated potassium channel slack. Nat Neurosci 13:819-821.

Charpak S, Gähwiler BH, Do KQ, Knöpfel T (1990) Potassium conductances in hippocampal neurons blocked by excitatory amino-acid transmitters. Nature 347:765-767.

Contractor A, Klyachko VA, Portera-Cailliau C (2015) Altered neuronal and circuit excitability in fragile X syndrome. Neuron 87:699-715.

Darnell JC, Van Driesche SJ, Zhang C, Hung KY, Mele A, Fraser CE, Stone EF, Chen C, Fak JJ, Chi SW, Licatalosi DD, Richter JD, Darnell RB (2011) FMRP stalls ribosomal translocation on mRNAs linked to synaptic function and autism. Cell 146:247-261.

Deng PY, Rotman Z, Blundon JA, Cho Y, Cui J, Cavalli V, Zakharenko SS, Klyachko VA (2013) FMRP regulates neurotransmitter release and synaptic information transmission by modulating action potential duration via BK channels. Neuron 77:696-711.

Deng PY, Carlin D, Oh YM, Myrick LK, Warren ST, Cavalli V, Klyachko VA (2019) Voltage-independent SK-channel dysfunction causes neuronal hyperexcitability in the hippocampus of Fmr1 knock-out mice. J Neurosci 39:28-43.

Desai MA, Conn PJ (1991) Excitatory effects of ACPD receptor activation in the hippocampus are mediated by direct effects on pyramidal cells and blockade of synaptic inhibition. J Neurophysiol 66:40-52.

Dictenberg JB, Swanger SA, Antar LN, Singer RH, Bassell GJ (2008) A direct role for FMRP in activity-dependent dendritic mRNA transport links filopodial-spine morphogenesis to fragile X syndrome. Dev Cell 14: 926-939.

El-Hassar L, Song L, Tan WJ, Large CH, Alvaro G, Santos-Sacchi J, Kaczmarek LK (2019) Modulators of Kv3 potassium channels rescue the auditory function of Fragile X mice. J Neurosci 39:4797-4813.

Ferron L, Nieto-Rostro M, Cassidy JS, Dolphin AC (2014) Fragile X mental retardation protein controls synaptic vesicle exocytosis by modulating N-type calcium channel density. Nat Commun 5:3628.

Gereau RW 4th, Conn PJ (1995) Roles of specific metabotropic glutamate receptor subtypes in regulation of hippocampal CA1 pyramidal cell excitability. J Neurophysiol 74:122-129.

Giorgi C, Yeo GW, Stone ME, Katz DB, Burge C, Turrigiano G, Moore MJ (2007) The EJC factor eIF4AIII modulates synaptic strength and neuronal protein expression. Cell 130:179-191.

Gross C, Nakamoto M, Yao X, Chan CB, Yim SY, Ye K, Warren ST, Bassell GJ (2010) Excess phosphoinositide 3-kinase subunit synthesis and activity as a novel therapeutic target in fragile $\mathrm{X}$ syndrome. J Neurosci 30: $10624-10638$

Gross C, Yao X, Pong DL, Jeromin A, Bassell GJ (2011) Fragile X mental retardation protein regulates protein expression and mRNA translation of the potassium channel Kv4.2. J Neurosci 31:5693-5698.

Hainsworth AH, McNaughton NC, Pereverzev A, Schneider T, Randall AD 
(2003) Actions of sipatrigine, 202W92 and lamotrigine on R-type and T-type $\mathrm{Ca}^{2+}$ channel currents. Eur J Pharmacol 467:77-80.

Hou L, Antion MD, Hu D, Spencer CM, Paylor R, Klann E (2006) Dynamic translational and proteasomal regulation of fragile $\mathrm{X}$ mental retardation protein controls mGluR-dependent long-term depression. Neuron 51:441-454.

Huber KM, Gallagher SM, Warren ST, Bear MF (2002) Altered synaptic plasticity in a mouse model of fragile X mental retardation. Proc Natl Acad Sci U S A 99:7746-7750.

Ifrim MF, Williams KR, Bassell GJ (2015) Single-molecule imaging of PSD-95 mRNA translation in dendrites and its dysregulation in a mouse model of fragile X syndrome. J Neurosci 35:7116-7130.

Kanai Y, Dohmae N, Hirokawa N (2004) Kinesin transports RNA: isolation and characterization of an RNA-transporting granule. Neuron 43:513-525.

Kuzmiski JB, Barr W, Zamponi GW, MacVicar BA (2005) Topiramate inhibits the initiation of plateau potentials in CA1 neurons by depressing R-type calcium channels. Epilepsia 46:481-489.

Lee HY, Ge WP, Huang W, He Y, Wang GX, Rowson-Baldwin A, Smith SJ, Jan YN, Jan LY (2011) Bidirectional regulation of dendritic voltagegated potassium channels by the fragile $\mathrm{X}$ mental retardation protein. Neuron 72:630-642.

Lee JH, Gomora JC, Cribbs LL, Perez-Reyes E (1999) Nickel block of three cloned T-type calcium channels: low concentrations selectively block alpha1H. Biophys J 77:3034-3042.

Magee JC, Carruth M (1999) Dendritic voltage-gated ion channels regulate the action potential firing mode of hippocampal CA1 pyramidal neurons. J Neurophysiol 82:1895-1901.

Magee JC, Johnston D (1995) Characterization of single voltage-gated $\mathrm{Na}^{+}$ and $\mathrm{Ca}^{2+}$ channels in apical dendrites of rat CA1 pyramidal neurons. J Physiol 487:67-90.

Menon L, Mader SA, Mihailescu MR (2008) Fragile X mental retardation protein interactions with the microtubule associated protein 1B RNA. RNA 14:1644-1655.

Meredith RM, Holmgren CD, Weidum M, Burnashev N, Mansvelder HD (2007) Increased threshold for spike-timing-dependent plasticity is caused by unreliable calcium signaling in mice lacking fragile $\mathrm{X}$ gene FMR1. Neuron 54:627-638.

Metz AE, Jarsky T, Martina M, Spruston N (2005) R-type calcium channels contribute to afterdepolarization and bursting in hippocampal CAl pyramidal neurons. J Neurosci 25:5763-5773.

Muddashetty RS, Kelić S, Gross C, Xu M, Bassell GJ (2007) Dysregulated metabotropic glutamate receptor-dependent translation of AMPA receptor and postsynaptic density-95 mRNAs at synapses in a mouse model of fragile X syndrome. J Neurosci 27:5338-5348.

Myrick LK, Deng PY, Hashimoto H, Oh YM, Cho Y, Poidevin MJ, Suhl JA, Visootsak J, Cavalli V, Jin P, Cheng X, Warren ST, Klyachko VA (2015) Independent role for presynaptic FMRP revealed by an FMR1 missense mutation associated with intellectual disability and seizures. Proc Natl Acad Sci U S A 112:949-956.

Nalavadi VC, Muddashetty RS, Gross C, Bassell GJ (2012) Dephosphorylation-induced ubiquitination and degradation of FMRP in dendrites: a role in immediate early mGluR-stimulated translation. J Neurosci 32:2582-2587.

Niere F, Wilkerson JR, Huber KM (2012) Evidence for a fragile X mental retardation protein-mediated translational switch in metabotropic glutamate receptor-triggered arc translation and long-term depression. J Neurosci 32:5924-5936.

Nosyreva ED, Huber KM (2006) Metabotropic receptor-dependent longterm depression persists in the absence of protein synthesis in the mouse model of fragile X syndrome. J Neurophysiol 95:3291-3295.

Oliet SH, Malenka RC, Nicoll RA (1997) Two distinct forms of long-term depression coexist in CA1 hippocampal pyramidal cells. Neuron 18:969-982.
Parajuli LK, Nakajima C, Kulik A, Matsui K, Schneider T, Shigemoto R, Fukazawa Y (2012) Quantitative regional and ultrastructural localization of the $\mathrm{Ca}(\mathrm{v}) 2.3$ subunit of R-type calcium channel in mouse brain. J Neurosci 32:13555-13567.

Park JY, Spruston N (2012) Synergistic actions of metabotropic acetylcholine and glutamate receptors on the excitability of hippocampal CA1 pyramidal neurons. J Neurosci 32:6081-6091.

Park JY, Remy S, Varela J, Cooper DC, Chung S, Kang HW, Lee JH, Spruston N (2010) A post-burst after depolarization is mediated by group I metabotropic glutamate receptor-dependent upregulation of $\mathrm{Ca}(\mathrm{v}) 2.3$ R-type calcium channels in CA1 pyramidal neurons. PLoS Biol 8:e1000534.

Richter JD, Bassell GJ, Klann E (2015) Dysregulation and restoration of translational homeostasis in fragile $\mathrm{X}$ syndrome. Nat Rev Neurosci 16:595-605.

Routh BN, Johnston D, Brager DH (2013) Loss of functional A-type potassium channels in the dendrites of CA1 pyramidal neurons from a mouse model of fragile X syndrome. J Neurosci 33:19442-19450.

Schaeffer C, Bardoni B, Mandel JL, Ehresmann B, Ehresmann C, Moine H (2001) The fragile $\mathrm{X}$ mental retardation protein binds specifically to its mRNA via a purine quartet motif. EMBO J 20:4803-4813.

Snyder EM, Philpot BD, Huber KM, Dong X, Fallon JR, Bear MF (2001) Internalization of ionotropic glutamate receptors in response to mGluR activation. Nat Neurosci 4:1079-1085.

Strumbos JG, Brown MR, Kronengold J, Polley DB, Kaczmarek LK (2010) Fragile X mental retardation protein is required for rapid experiencedependent regulation of the potassium channel Kv3.1b. J Neurosci 30:10263-10271.

Takahashi H, Magee JC (2009) Pathway interactions and synaptic plasticity in the dendritic tuft regions of CAl pyramidal neurons. Neuron 62:102-111.

Ulbrich MH, Isacoff EY (2007) Subunit counting in membrane-bound proteins. Nat Methods 4:319-321.

Waung MW, Huber KM (2009) Protein translation in synaptic plasticity: mGluR-LTD, Fragile X. Curr Opin Neurobiol 19:319-326.

Weiergräber M, Henry M, Krieger A, Kamp M, Radhakrishnan K, Hescheler J, Schneider T (2006) Altered seizure susceptibility in mice lacking the $\mathrm{Ca}(\mathrm{v}) 2.3$ E-type $\mathrm{Ca}^{2+}$ channel. Epilepsia 47:839-850.

Weiergräber M, Henry M, Radhakrishnan K, Hescheler J, Schneider T (2007) Hippocampal seizure resistance and reduced neuronal excitotoxicity in mice lacking the Cav2.3 E/R-type voltage-gated calcium channel. J Neurophysiol 97:3660-3669.

Williams ME, Marubio LM, Deal CR, Hans M, Brust PF, Philipson LH, Miller RJ, Johnson EC, Harpold MM, Ellis SB (1994) Structure and functional characterization of neuronal alpha $1 \mathrm{E}$ calcium channel subtypes. J Biol Chem 269:22347-22357.

Zalfa F, Giorgi M, Primerano B, Moro A, Di Penta A, Reis S, Oostra B, Bagni C (2003) The fragile X syndrome protein FMRP associates with BC1 RNA and regulates the translation of specific mRNAs at synapses. Cell 112:317-327.

Zalfa F, Eleuteri B, Dickson KS, Mercaldo V, De Rubeis S, di Penta A, Tabolacci E, Chiurazzi P, Neri G, Grant SG, Bagni C (2007) A new function for the fragile $\mathrm{X}$ mental retardation protein in regulation of PSD-95 mRNA stability. Nat Neurosci 10:578-587.

Zamponi GW, Bourinet E, Snutch TP (1996) Nickel block of a family of neuronal calcium channels: subtype- and subunit-dependent action at multiple sites. J Membr Biol 151:77-90.

Zhang Y, Bonnan A, Bony G, Ferezou I, Pietropaolo S, Ginger M, Sans N, Rossier J, Oostra B, LeMasson G, Frick A (2014) Dendritic channelopathies contribute to neocortical and sensory hyperexcitability in Fmrl(-/y) mice. Nat Neurosci 17:1701-1709. 